\title{
THE CASE FOR THE CONSTITUTIONALITY OF THE SOCIAL SECURITY ACT
}

\author{
Harry Shulmax*
}

The lawyer's task in this symposium is simple and unhappy. He need not speculate about the effects of the Social Security Act on life, on business, on government. He need not concern himself about the probabilities of expected benefits or suggested evils. Those thrilling jobs have been assigned exclusively to other contributors. Moreover, constitutional dogma teaches that, in his professional capacity of advising on constitutionality, the lawyer, as the judge, need not even persuade himself of the wisdom or folly, the desirability or undesirability, of the legislation-not even that the legislation is perhaps a little more wise than foolish or a little more foolish than wise. It is sufficient if the legislative determination has some reasonable support. The work of the Committee on Economic Security, the legislative hearings and the remainder of this symposium establish that support-and beyond peradventure. So the lawyer's job is simple: "to lay the article of the Constitution which is invoked beside the statute which is challenged" and, "uninfluenced by predilection for or against the policy disclosed in the legislation," see "whether the latter squares with the former."

Observers of the Supreme Court's work tell us, however, that the lawyer's job is not so mechanical. He must determine not whether the legislation squares with the Constitution but rather how the tribunal having the power of ultimate decision will decide. When the Supreme Court is that tribunal, he must guess what at least five of the nine Justices will decide. Their decision, he is told, may be influenr-t by conscious or subconscious predilections, by earlier conditioning and by psychological factors of varying degrees of unpredictability. And certainly, decision involves either intelligent comprehension or mistaken distortion of the problems with which the legislation deals, the difficulties which they present, the manner in which the legislation deals with them and the problems of choice which were resolved by the adoption of that method. The lawyer's job, then, involves all the speculation and uncer-

-A.B., I923, Brown University; LL.B., x926, S.J.D., r927, Harvard University. Member of the New York and Rhode Island Bars. Associate Professor of Law, Yale University School of Law. Special Counsel, Railroad Retirement Board. Law clerk to Mr. Justice Brandeis, United States Supreme Court, 1929-1930. Contributor to legal periodicals.

${ }^{1}$ U. S. v. Butler, 56 Sup. Ct. 312, 318, 325 (r936); Railroad Retirement Board v. Alton R. R., 295 U. S. 330,346 (I935). 
tainty inherent in economic or social forecasting. Yet, the economist or sociologist is rarely proved to his own satisfaction completely, or even partly, wrong. He can lay non-realization of his prophecy, not to his error, but to the intervention of other factors; or he can urge that conditions would have been still better or worse had his suggestions been followed or rejected. But the lawyer has no such solace. When the Supreme Court has decided, his prediction was either right or wrong, and beyond cavil-unless, indeed, he can find comfort in the thought, expressed by a distinguished veteran of the bar, "the Supreme Court may not accept these views, but I regard them as sound."

Moreover, the recent T.V.A. decision reminds, at an opportune time, that it is not constitutional to pass on constitutionality in the abstract. Judical decision must be rendered only with respect to specific issues raised by specific parties having specific interest in a specific case within judicial cognizance. No court is empowered by the Constitution to render opinions on the constitutionality of legislation: The Supreme Court's power, like that of the inferior federal courts, is only that of deciding cases or controversies appropriate for the exercise of the federal judicial power. In adjudicating such cases the Court may find it imperative to disregard legislation because it conflicts with the Constitution. But beyond yielding to this imperative necessity, as encountered and only to the extent encountered in cases before it, the Court may not inquire into the constitutionality of congressional legislation. ${ }^{2}$ This theory need not be idle liturgy. It should have substantial practical significance. For, since neither the Constitution nor constitutional theory sets up the juidiciary as a third branch of the government to advise on constitutionality and since neither the Constitution nor constitutional theory creates cases or controversies through which constitutionality is to be determined by the judiciary, some legislation, a least, may be beyond the scope of judicial review on this orthodox theory. In such cases, determination of constitutionality rests with the other branches of the government; and the enactment of the legislation is conclusive of its constitutionality until there is a change of mind in those branches. An outstanding feature of the recent work of the Supreme Court has been the expansion of the area in which it exercises power. ${ }^{3}$ But that expansion, like other constitutional determinations, has divided the Court and is subject to the possibilities of the future. There is still vitality in the orthodox theory and it has considerable significance in discussions of the constitutionality of the Social Security Act.

\footnotetext{
${ }^{2}$ Ashwander v. Tennessee Valley Authority, 56 Sup. Ct. 466 (I936). Both major opinions profess this dogma and both are limited in deference to it, though in different ways. The opinion of Mr. Justice Brandeis refuses to deal at all with the constitutionality of T.V.A.; and the opinion of the Chief Justice deals with the problem only as related to the Wilson Dam.

${ }^{8}$ E.g., U. S. v. Constantine, 56 Sup. Ct. 223 (I935); Colgate v. Harvey, 56 Sup. Ct. 252 (1935); U. S. v. Butler, 56 Sup. Ct. 312 (1936); Rickert Rice Mills, Inc. v. Fontenot, 56 Sup. Ct. 249, 374 (I936); Gt. No. Ry. v. Weeks, 56 Sup. Ct. 426 (1936); Ashwander v. T.V.A., 56 Sup. Ct. 466 (1936); see Collier, Iudicial Bootstraps and the General Welfare Clause (1936) 4 Geo. WAsH. L. REv. $211,217$.
} 


\section{Titres I, III, IV, V, VI, X}

These titles, which respectively envisage grants to the states for old-age assistance, unemployment compensation administration, aid to dependent children, maternal and child welfare, public health work, and aid to the blind, may be considered together. ${ }^{4}$ None operates on individuals. None requires action from individuals. All merely provide for federal grants of money to the states, which the states may take or reject, to aid the states in their performance of the named objects. Some limit the amount of the federal grant to a percentage of the total to be expended by the states and condition the grant upon financial participation by the states. Others make outright grants not conditioned upon any state financial participation. All impose conditions upon the administration and expenditure of the funds.

Unless the Supreme Court turns its back on a century of constitutionalism and the judicial power is expanded beyond even its present wide borders, these grantsin-aid are constitutional so long as Congress deems them so. For, while similar grants-in-aid have been common in our history, the Supreme Court has expressly disclaimed power to review their constitutionality. In Frothingham v. Mellon and in Massachusetts v. Mellon ${ }^{5}$ the Court held that neither a general taxpayer nor the state had a standing to question the appropriations under the Sheppard-Towner Maternity Act. ${ }^{6}$ Whether the taxpayer pays small or huge taxes is immaterial, as indicated in the opinion of the Chief Justice in the T.V.A. case. ${ }^{7}$ The point is that the taxpayer's money is collected for the general use of the government and is not earmarked for a particular purpose or specifically imposed to recompense for particular expenditures. ${ }^{8}$ Unlike the processing taxes of the A.A.A., Mrs. Frothingham's taxes were not special taxes imposed in connection with the special scheme of expenditures. The processors were successful in their challenge of the A.A.A. taxes because the Court regarded that Act as "one regulating agricultural production" with the tax "a mere incident of the regulation" and an "exaction" from the processors for bestowal upon the farmers. But the authority of the Maternity cases

-In conversation Title III is commonly linked with Title IX. Naturally, since both selate to unemployment compensation. But for the purpose of inquiring into their constitutionality there is little justification for linking the two titles together. It can hardly be said that the Title IX tax is imposed for the purpose of balancing the Title III appropriation. If the purpose of both titles is to encourage state unemployment compensation plans, nevertheless they are not integral parts of a single scheme; each holds forth a separate inducement. Since they are separate titles and since there is not even a budgetary relation between them-and particularly in view of the separability clause-the constitutionality of each may be considered independently of the other. The validity of Title IX will be considered presently. If that title is deemed valid, when considered by itself, it seems inconceivable that its legality is affected by Title III. Conversely, if that title is held invalid, when considered by itself, Title III cannot alter the judgment, but likewise, Title III need not automatically suffer the same fate.

${ }^{5} 262$ U. S. 447 (1923).

${ }^{7} 56$ Sup. Ct. at 470 : "While their stock holdings are small, they have a real interest. . . . If otherwise entitled, they should not be denied the relief which would be accorded to one who owned more shares."

${ }^{8}$ With respect to the state's suit, there was the additional ground that, since "nothing has been done and nothing is to be done" under the statute without the states' consent, "it is plain that the question, as it is thus presented, is political and not judicial in character, and therefore is not a matter which admits of the exercise of the judicial power." 262 U. S. 447 at 483 . 
was expressly saved. ${ }^{9}$ It seems unlikely that the Court will dub the past practice a "century of error" and undertake to review general government expenditures at the suit of a general taxpayer or a state.

The grants-in-aid of the Social Security Act are quite like those of the Maternity Act. Both acts provide for appropriations from general funds in the Treasury. Neither requires or contemplates special taxes to balance the expenditures. Indeed, Title $V$ provides federal expenditures for the very same purposes as the Maternity Act, and Part 4 of Title V implements the Vocational Rehabilitation Act previously in force. The objects of the other grants are of the same character as maternal welfare. On the issue whether federal expenditures for their welfare are subject to judicial review, constitutional law does not differentiate between child-bearing mothers and the blind, the aged, or the crippled children; nor is public health service or the administration of unemployment compensation on a different constitutional plane. ${ }^{10}$

If there is no procedure whereby these grants may be subjected to judicial review, then Congress, not the Court, is the ultimate judge of their constitutionality. And if the issue of constitutionality should be raised in Congress, the argument for validity is quite convincing. A century of practice and an abundance of persuasive precedent are alone weighty considerations. The appropriations are for the "general welfare" in any intelligible meaning of that phrase. They operate throughout the nation to aid the states in relieving distress common in all of them, common, that is, in the nation and directly affecting the national welfare. The states' need of federal aid in providing for this relief is the outstanding lesson of our current history and is conceded by all shades of political belief. The expenditures are administered by the states. They involve no element of regulation or coercion of the kind found by the Court in the A.A.A. or of any kind. The federal government is not superseding the state or invading its powers, but on the contrary is aiding it and strengthening its efforts.

But even a more limited interpretation of general welfare would include the national interest in the nation's man-power in connection with its responsibilities for war and interstate and foreign commerce. The relationship of public health service and child and maternal welfare on a national scale to the maintenance of that man-power is quite clear. No less is the nation's concern with the effect on its man-power of the distress of the aged and unemployed when that distress becomes a national phenomenon. The argument is not that under its interstate commerce or war powers, the Congress can enact any legislation which would affect the objects of those powers, but rather that the nation's interest in war and commerce is relevant in determining whether the general warfare is promoted by an exercise of the inde-

${ }^{0}{ }_{5}$ Sup. Ct. 312, 315-17.

${ }^{10}$ Part C, pp. 61-69, of the Appendix to the Brief for the United States in the A.A.A. case contains a collection of many previous grants in aid. See also Horack, Federal-State Coöperation for Social Security: The Grant-in-Aid (1935) 30 ILL. L. Rev. 292. 
pendent power of appropriation. Whether or not the nation may regulate industry or individual conduct to prevent such distress, an unencumbered appropriation of money to be expended by the states for such relief-expenditures calculated to promote stability in purchasing power, to foster physical health, and to avoid starvation or demoralization throughout the population-is surely for the general welfare even when that phrase is narrowed in meaning.

"The aged" should not be given a literal meaning which would distort the purpose of the Act. The term refers not so much to a category of persons as to a type of social maladjustment affecting the population generally. Aged persons are not a group detached from persons as a whole. They are bound to the rest of the population by family and economic ties which prevent segregation or isolation. The support of aged persons casts a heavy burden on their younger relatives. Suffering or demoralization among the aged means also suffering and demoralization among the younger members of their families. Relief for the aged is relief, moral and . economic, for the young-relief for the population generally. "The aged" describes, not the beneficiaries of the legislation, but the medium through which the general welfare is sought to be promoted.

It may be suggested that the grants are in fact encumbered by conditions which make a difference;-conditions requiring financial participation by the states, statewide operation of the state plans, reports to the Social Security Board, administration or supervision by a single state agency and with approved methods, fair hearings for aggrieved individuals and avoidance of unapproved residence or citizenship requirements. But similar conditions commonly encumbered grants-in-aid made in the past. ${ }^{11}$ All of them relate solely to the administration and expenditure of the funds appropriated. None of them requires conduct unrelated to the expenditure. All are prudent safeguards dictated by experience to insure economical rather than wasteful expenditure of the funds, by agencies financially interested rather than agencies dealing only with "other people's money," for the objects stated rather than for wasteful administration, openly and under public scrutiny rather than in official secrecy, for the national welfare rather than for local or individual preferment. None of these conditions has any resemblance to those condemned in the A.A.A. case. It would be the absence of such prudential conditions, rather than their presence, which might condemn the Act.

\section{TITLE VIII}

The power of Congress to "lay and collect taxes, duties, imposts and excises, to pay the debts and provide for the common defense and general welfare of the United

${ }^{11}$ E.g., the Maternity Act required state participation, a state agency, reports by the state agency to the Federal Children's Bureau, approval of state plans by the federal board, and prohibition in the state plans against taking children over parents' objections; it prohibited the use of the grant for the purchase, erection or repair of buildings or equipment and required that the money appropriated by the states be not used for the payment "of any maternity or infancy pension, stipend, or gratuity"; and it authorized the withholding of the federal funds upon a finding that the state agency "has not properly expended the money paid to it or the moneys herein required to be appropriated by such State." 42 STAT, 224-26. 
States"12 has few limitations in the Constitution. There is first the limitation in that very grant of power; and there is the further provision in the same section that "all duties, imposts and excises shall be uniform throughout the United States." Section 9 of Article I also provides that "no capitation, or other direct, tax shall be laid unless in proportion to the census or enumeration ...;" and this prohibition is modified by the Sixteenth Amendment which authorizes "taxes on incomes, from whatever source derived, without apportionment among the several states and without regard to any census or enumeration." To these limitations of the Constitution must be added those of the judicial gloss, ${ }^{13}$ that the tax must be really a tax and not a penalty for conduct which Congress may not otherwise penalize, ${ }^{14}$ that it must be a true tax rather than a disguise for, or an integral part of, a scheme of regulation which Congress may not enact directly ${ }_{15}^{15}$ that it must be a tax rather than an exaction so arbitrary and capricious as to constitute a deprivation of property without due process of law. ${ }^{16}$

The immediate purpose of the taxes imposed by Title VIII is unquestionably to raise revenue. They are, therefore, not subject to the weakness of the taxes condemned in the Child Labor Tax Case ${ }^{17}$ or Hill v. Wallace. ${ }^{18}$ In those cases, the taxes were regarded as penalties or regulations because the government obviously did not desire revenue to result from their imposition. The taxes were imposed for prescribed conduct which it was clearly hoped would be abandoned under their compulsion. But it is even clearer that Title VIII is not intended to discourage employment, that its success depends upon the production of revenue rather than avoidance of the tax by abandonment of stated conduct. The taxes are not penalties. Likewise, neither Title VIII nor the remainder of the Act attempts to regulate the conduct of the taxpayers, or of any other individuals, beyond requiring them to pay the taxes and make the returns incident to tax collection. The taxes are consequently not regulations, unless the possible expenditures work a conversion, but that issue may be postponed for the moment.

The subjects of the tax seem to be clearly within the limits of the constitutional grant of power to levy "taxes, duties, imports and excises." It is needless to determine what the nature of the tax is, for it certainly falls within one of the four designations. The choice of subjects is unlimited except by the uniformity and apportionment provisions and, perhaps, by the due process clause of the Fifth Amendment. The uniformity clause requires only geographical uniformity, that is, opera-

19 U. S. Const., ARr. I, \$8.

${ }^{2 s}$ For full analysis of that gloss, see Powell, Child Labor, Congress, and the Constitution (I922) I N. C. L. Rev. 6r; Cushman, Social and Economic Control Through Federal Taxation (I933) I8 Mins. L. REv. 757 .

2" Child Labor Tax Case, 259 U. S. 20 (I922); Hill v. Wallace, 259 U. S. 44 (I922); U. S. v. Constantine, 56 Sup. Ct. 223 (1935).

${ }^{15}$ U. S. v. Butler, 56 Sup. Ct. 312 (1935).

${ }^{10}$ Nichols v. Coolidge, 274 U. S. 531 (1927); Untermyer v. Anderson, 276 U. S. 440 (1928); Heiner v. Donnan, 285 U. S. 312 (1932).

${ }^{17}$ Supra note $\mathrm{r} 4$.

${ }^{18}$ Supra note $x_{4}$. 
tion throughout the United States. ${ }^{19}$ Title VIII does so operate. The apportionment provision is applicable only to capitation and other "direct" taxes. Title VIII levies neither kind. The taxes are not on the ownership of property or the income from property so as to fall under the ban of unapportioned "direct" taxes. ${ }^{20}$ The employer's tax refers to his employment of individuals, regardless of whether or not he has property or income from property. The employee's tax is levied on his income not from property but from personal service, a subject available for taxation without apportionment even before the Sixteenth Amendment. ${ }^{21}$ Employment of others and the derivation of income from personal labor are readily ascertainable economic functions and are, therefore, within the range of subjects available for federal taxation.

The selection of employment and wages for taxation can hardly offend the due process clause so as to render the tax in fact an arbitrary deprivation of property. There is no requirement that the same taxes be levied on all persons in the country. Congress, like the legislatures of all other governments, has made special selections throughout our entire history as a nation. Manufacture of tobacco and liquors, sugar refining, use of foreign-built yachts, mining, sales of securities, theatre tickets, gasoline, and luxuries generally, gifts, inheritances, narcotics, land deeds and other legal documents-these and numerous other things have been subjected to separate federal taxation. $^{22}$ The Congressional choice of subjects is quite unlimited.

But attack may be directed at the exemptions. Employers may urge that due process under the Fifth Amendment implies equal protection of the laws and that equality is denied by the exemption of employers mentioned in Section 8Ir. It is doubtful whether the Fifth Amendment is such a limitation upon the taxing power as to require even the rough approximations of equality required of state laws by the Fourteenth Amendment which expressly commands equal protection. The power of selection already discussed is a power to exempt. The difference is only in verbal statement. The subject of the tax may.be narrowly defined so as to exclude certain persons by negative implication or it may be defined more broadly with express exemption of the same persons sought to be excluded. There is no case in which such an attack upon a federal tax has been sustained or even encouraged., ${ }^{23}$

${ }^{10}$ Knowlton v. Moore, 178 U. S. $4 x$ (1900); Bromley v. McCaughn, 280 U. S. 124 (1929).

20 Pollock v. Farmers' Loan \& Trust Co., 158 U. S. 60I (1895); Dawson v. Kentucky Distillerics Co., 255 U. S. 288 (I92I); Bromley v. McCaughn, 280 U. S. 124 (1929).

${ }^{21}$ Pollock v. Farmers' Loan \& Trust Co., supra note 18.

$\approx$ Almost any general revenue act since the war provides abundant precedent for broad Congressional discretion in the selection of subjects for taxation. And see Hylton v. U. S., 3 Dall. 171 (1796); Veazic Bank v. Fenno, 8 Wall. $533^{\circ}$ (U. S. I869); Nicol v. Ames, I73 U. S. 509 (I899); Thomas v. U. S., 192 U. S. 363 (1904); Spreckles Sugar Refining Co. v. McClain, I92 U. S. 397 (1904); McCray v. U. S., 195 U. S. 27. (1904); Flint v. Stone Tracy Co., 220 U. S. 107 (191I); Billings v. U. S., 232 U. S. 26I (1914); Bromley v. McCaughn, 280 U. S. 124 (1929); cf. Edelman v. Boeing Air Transp., 289 U. S. 249 (1933); Fox v. Standard .Oil Co., 294 U. S. 87 (I935). The Court has sustained selection, for taxation, of anthracite coal from all other coal, Heisler v. Thomas Colliery Co., 260 U. S. 245 (1922), of herring from all other fish, Alaska Fish Co. v. Smith, 255 U. S. 44 (I921).

${ }^{3}$ On the contrary, the Court has discouraged such attacks: "Except in rare and special instances, the due process of law clause contained in the Fifth Amendment is not a limitation upon the taxing power 
But even were it otherwise, the exemptions have ample justification. (I) Exemption of employment by a state and its subdivisions is justified by constitutional limitations which are similarly operative on the general income tax. (2) A tax by the federal government on itself and its instrumentalities as employer will hardly be urged. (3) Exemption of religious, charitable and educational institutions has historic precedent and long tradition as justification, apart from other considerations relating to this specific tax. (4) Likewise exemption of agricultural labor, domestic service and service performed by crews on vessels-simply because of their intrinsic difference from other employment-has sufficient precedent in past practice. ${ }^{24}$ And there are additional considerations. It would be strangely inconsistent, at least now, for the government to increase the tax burden on agriculture while it is at the same time searching for means to lift agriculture from its financial plight. The compensation of all three classes of employment consists largely of maintenance and only partly of money. Collection of the tax might cost more than the tax would bring. (5) The similar burden of expenditure and the annoyance to the taxpayer suffice to justify the exemption of casual labor. (6) Exemption of service performed by a person who is over 65 years of age may be rested on the desire not to afford additional encouragement for the discharge of, or refusal to employ, such persons, whose age alone puts them at a disadvantage.

- These answers may also be made to the complaint that the employee's tax makes the same exemptions. But here there is the additional quite conclusive answer that the exempt employees are not given any benefits under Title II of the Act. This is equally the response to the objection, that the tax is levied only on wage incomeapart from the additional fact that it has long been held that an income tax need not include income from all sources. ${ }^{25}$

There are other minor objections of inequality. The taxes are not levied on wagès over $\$ 3,000$. An employer having one employee to whom he pays $\$ 6,000$ is taxed upon $\$ 3,000$, while an employer having two employees throughout the year to each of whom he pays $\$ 3,000$ or one employee for six months at $\$ 3,000$ and a different employee for the other six months, also at $\$ 3,000$, is taxed upon $\$ 6,000$. An employee earning $\$ 6,000$ from one employer is taxed on $\$ 3,000$ while an employee earning $\$ 3,000$ from each of two employees is taxed on $\$ 6,000$. Such objections assume that the due process clause is an especially sensitive instrument which can cut exceedingly fine. And they would turn attention away from major features to minutiae which are of little importance and which can be readily corrected if found

conferred upon Congress by the Constitution." Magnano v. Hamilton, 292 U. S. 40, 44 (1934). See also Brushaber v. Union Pacific R. R., 240 U. S. I (1916) where objections to tax exemptions similar to those in the Social Security Act were held to be without substance. The federal taxes which have been declared unconstitutional under the due process clause have been only those which the Court deemed to be retroactive; note 16 , supra.

${ }^{\sharp}$ E.g., workmen's compensation acts, taxes on motor vehicles and gasoline.

$\approx$ Pollock v. Farmers' Loan \& Trust Co., supra note 20; Brushaber v. Union Pacific R. R., supra note 23; cf. Klein v. Board of Tax Supervisors, 282 U. S. 19 (1930). 
faulty. But each of the objections may be met. The government, in need of revenue, may, well decide to broaden its tax base and avoid cumulation of taxes. The \$3,000 limitation may be the result of such an effort. Income above that amount is subject to the graduated income tax. The possible difference in the employers' tax which may result differences in the number of employees to whom the same aggregate amount of wages is paid is the result, not of unequal, but of equal, treatment. The tax is on the privilege of employment and the privilege is exercised to a greater extent when a greater number of employees are employed. The number of employees and the amount of wages paid are both reasonable measures for the tax. ${ }^{20}$ As for the employee who pays a higher tax because he receives wages from two employers rather than one, a sufficient answer may be the practical difficulties of administration which would be involved if the employer's records could not form the basis for assessment and collection. ${ }^{27}$ "In another sense, moreover, there is equality." The income tax is an excise on being employed by another for wages. Two employments may, again, be regarded as a greater exercise of the privilege than one. ${ }^{28}$ Like the "numerous and minute, not to say in many respects hypercritical contentions" made in the Brushaber case, the objections here "rest upon the mistaken theory that although there be differences between the subjects taxed, to differently tax them transcends the limit of taxation and amounts to a want of due process." ${ }^{20}$ "It is a sufficient answer to say that you cannot carry a constitution out with mathematical nicety to logical extremes." 30

\section{TIrLE II}

The scheme of the Act reflects the hope that the validity of the taxes might be determined without investigation of the expenditure of the funds collected. With the validity of the taxes thus determined, there would then be no one, in view of Frothingham v. Mellon, who could question before the courts the general validity of the appropriations and expenditures. But the A.A.A. decision has shaken the foundation for that hope. It is still true, of course, that there is no express tie-up

\footnotetext{
${ }^{20}$ Chain store taxes based on the number of stores, regardless of their revenues, have been upheld despite objection under the equal protection clause. See Fox v. Standard Oil Co., supra note 22. Likewise, with respect to the objection that an employer of one person at $\$ 3,000$; pays a higher tax than an employer of two persons at $\$ 1,000$ each, there is precedent in sales taxes.generally. A purchaser of a $\$ 60$ suit pays a higher tax than a purchaser of two $\$ 20$ suits. And see Bromley v. McCaughn, 280 U. S. I24 (1929), where the gift tax was challenged because, by virtue of graduation and exemption, "the tax levied upon donors of the same total amounts may be affected by the size of the gifts to individual donees." The challenge was, of course, unsuccessful. License fees are frequently fixed at a flat sum without reference to the amount of business done by licensees, or are graduated to a maximum which disregards differences above a certain point.

${ }^{\prime}$ N. Y. ex rel. Hatch v. Reardon, 204 U. S. 152 (I907), involved a stamp tax of two cents on cach hundred dollars of face value of stock for every sale or agreement to sell the same. The tax was challenged under the due process clause because face value rather than actual value was the measure. Said the Court: "The inequality of the tax, so far as actual values are concerned, is manifest. But, here again equality in this sense has to yield to practical considerations and usage" (at p. 159).

${ }^{23}$ Cf. N. Y. ex rel. Hatch v. Reardon, supra note 27.

${ }^{20}$ Brushaber v. Union Pacific R. R., 240 U. S. I, 24, 26 (Igr6).

${ }^{80}$ Paddle v. New York, 2 II U. S. 446,450 (Ig08).
} 
between the taxes levied by Title VIII and the appropriations authorized by any other title of the Act. The taxes are not earmarked but go into the general funds of the government. The appropriations are to be made from the general funds. There is no exact or textual correspondence between the amounts of the appropriations and the amounts expected from the taxes. And there is no express dependence of one upon the other. The appropriations are authorized without reference to possible experience in the tax collection.

It is generally charged, however, that there is at least a budgetary correspondence between Title II and Title VIII, that the taxes are imposed to balance the appropriations authorized so that the federal budget will not be distorted. Assume, therefore, that in its inquiry as to the validity of the taxes, the Court professes power to inquire also into the budget and is convinced that Title II is the sine qua non-and major justification for the tax. As stated previously, no amount of analysis or psychoanalysis of the Act can disclose any purpose for the tax other than that of raising revenue. Unlike tax acts previously declared unconstitutional, this Act is obviously intended to promote rather than retard the frequency of the subject taxed, to 'raise more and more rather than less and less revenue. And unlike the A.A.A. expenditures, the Title II expenditures are to be made without requiring anybody, by way of contract or condition, to act or refrain from acting in any manner. There is no penalty, no regulation, no attempt to "purchase compliance,"-only a tax and an expenditure. The benefits are paid only to those aged who do not continue in employment. But they are neither coerced nor tempted by the Act to retire from service. The benefit payments are considerably smaller than wages. A person who chooses to remain in service after 65 receives his wages rather than benefits until he is retired. He prejudices in no way his right to benefits upon retirement, the amount of the monthly benefits, or the amount of the death payments. The provision is simply that an individual shall not be paid both benefits and wages for the same month. To regard this as a coercion or purchase of retirement comes close to regarding unemployment relief or poor relief as a coercion or purchase of unemployment or poverty.

Is the appropriation one for the common defense and general welfare? In the A.A.A. case the Court concluded that the general welfare was sought to be promoted not by the simple donation of money but by the purchase with that money of restraints which Congress was otherwise unauthorized to impose. On the interpretation of the general welfare clause, however, the Court adopted unreservedly the so-called broad or Hamiltonian point of view that the power to authorize expenditures of public money is not confined in its objectives to the other enumerated powers of the federal government but may be exercised broadly for the promotion of the national general welfare. The Court expressly declined "to ascertain the scope of the phrase 'general welfare of the United States' or to determine whether an 
appropriation in aid of agriculture falls within it."31 The Court has undertaken to ascertain whether a tax is, in its view, truly that or something else. But it has never undertaken to ascertain whether the object of an appropriation is, in its view, the general welfare. In a century and a half of history that issue has been left to the judgminent of Congress.

Unless one is to set himself up as an omniscient economist or sociologist with unerring prophetic wisdom, it must be conceded that there-is abundant support for the Congressional determination that the tax and expenditure will promote the constitutional objectives. The Act operates throughout the United States on a universal phenomenon-advancing age. It promises to introduce for the American population as a whole a more certain income, a more continuous purchasing power, a more secure future. It is expected thus to promote general prosperity, avoid precipitate dips of depression and foster our national commerce. And it is expected thus to produce a healthier, more confident, more contented and more loyal citizenry-for common defense and general welfare in war and in peace. Expenditures for a national monument at Gettysburg ${ }^{32}$ or for bonuses or pensions to ex-soldiers are hardly more closely related to the future common defense and general welfare. of the United States than expenditures for assurance of security to the national population and for lightening the burden on the young generation to support the old.

There is another close federal purpose-the purpose to protect the government finances. Under Title I of the Act, the federal government has undertaken to aid the states financially in the provision of relief for the needy aged. It. is quite clear that federal aid will be necessary and will be extended so long as the need for relief continues. The constitutionality of federal expenditures for this purpose has already been discussed. As a practical matter, regardless of individual private opinion, those expenditures are constitutional and we can start with that as a datum. Whether such expenditures by the federal government will be required continuously or only in the recurrent periods of depression is not material for the present point. The fact is that the federal government is under a present and potential liability to provide large sums of money for the relief of the needy aged. Now the evidence is convincing that the numbers of aged and needy aged in our population will constantly increase for a considerable period in the future, and that the expenditures for relief to the needy aged will, for that reason and others, mount at a rapid rate. The financial burden on the federal government, therefore, threatens to be quite heavy. To ease that burden and provide against it by application to its source is one function of Title II. In a large sense, it is a civilized substitute for an, old and now unsatisfactory system of relief. Insofar, then, as the Title VIII taxes are provisions against anticipated federal obligations, they are the result of a typical and traditional exercise of the taxing power.

\footnotetext{
56 Sup. Ct. at 320 .

${ }^{82}$ U. S. v. Gettysburg Electric Ry., 160 U. S. 668 (I896).
} 
Of course, Title II is not limited to relief of the needy aged. A very substantial portion of the beneficiaries of Title II will be needy. Another portion would be needy but for the operation of the Act. Some probably will not and' would not be needy. Title II is not merely a palliative. It attempts to cure the condition and prevent its recurrence. It is a civilized measure precisely because it is focussed on the social problem rather than on the individual symptoms. And it is certainly wise statesmanship that a provision against future obligations should rely upon systematic, automatic administration and avoid the costs, the wastes, the dissatisfactions, the humiliations and the dangers of individual determinations of need.

What has been said would seem to answer the possible objection that the Act invades the powers reserved to the states by the Tenth Amendment. Provision of the kind of benefits contemplated by Title II can hardly be regarded as of merely local concern in view of our own recent history and the history of all other industrial countries. The national interest in the welfare of the national population is obvious. That the Act is calculated to promote that welfare is also clear. The issue is only whether the nation has power to enact the specific legislation in furtherance of that interest. National interest in the general welfare has been deemed insufficient to warrant coercive national regulation of local commerce, even though that regulation might promote the general welfare, because the national power to regulate commerce is limited to interstate commerce. But the criterion of the power to tax and appropriate is only the purpose to promote the general welfare. That power expressly conferred is, as the Chief Justice stated in the T.V.A. case, not abridged by the Tenth Amendment. ${ }^{33}$ Granted that Titles VIII and II only tax and appropriate, then they are within Congressional power. The A.A.A. case and its predecessors contain, as pointed out above, no warrant for a contrary holding. In all of them, the legislation did more than tax and appropriate.

The charge that while the tax is not a penalty or regulation it is still not a "true" tax but rather an "exaction" or "expropriation of money from one group for the benefit of another" in violation of the due process clause is largely unfounded invective. It is difficult to think of the persons taxed under Title VIII and the persons entitled to benefits under Title II as different "groups." If the funds required under Title II were collected by means of some other general tax, a sales tax or the income tax, the charge could hardly be made. In a sense all taxes are exactions of money from one group for the benefit of another. No expenditure returns to the taxpayer direct benefits, or indirect benefits through the general welfare, exactly proportioned to his tax payments. Tax money expended for soldiers' bonuses, for relief of the unemployed and the needy, and for pensions to Presidents' widows and civil servants is in direct form money exacted from one group for the benefit of another. In substance the case is no less clear with respect to the protective tariff and

${ }^{2} 56$ Sup. Ct. at 475 : "To the extent that the power of disposition is thus expressly conferred, it is manifest that the Tenth Amendment is not applicable. And the Ninth Amendment ... does not withdraw the rights which are expressly granted to the federal government." 
the taxes paid by that class of the population who smoke tobacco and drink liquor. Yet that is hardly expropriation. The legislative determination that the taxes and expenditures are for the general welfare is a determination that they are for the benefit of the taxpayers as well as the direct recipients of the expenditures. There is, and can be, no requirement that taxes or expenditures benefit all taxpayers in precisely the same manner or in degrees exactly proportioned to their taxes. The charge of "expropriation" raises no new issue even though it points to a psychological hazard.

Similar is the charge that by Titles VIII and II the federal government has embarked upon the insurance business in competition with private enterprise. In point of fact, the statement is quite untrue. There is practically no private enterprise in the limited field in which these titles operate. And there is practically no prospect that private enterprise can or will occupy the field. But legally, the charge even if true does not condemn. If competition with private enterprise is the consequence of an exercise of a power granted by the Constitution, then it is a consequence permitted by the Constitution. The fact of competition with private enterprise was accorded no significance in the T.V.A. case because competition was the necessary consequence of the granted power to dispose of property properly acquired. Yet there the competition was real and obvious. And the Court sanctioned a disposal of the property in not the least but in the most competitive manner. It sanctioned the purchase of transmission lines, as an incident of the power to dispose, in order to effect a more competitive disposal. Titles VIII and II do.nothing more than tax and give for the general welfare-powers admittedly granted to Congress.

It may be said, however, that the field is reserved for private enterprise regardless of whether or not private enterprise has chosen to occupy it. But constitutional law does not define the kind of enterprises into which government may enter beyond prescribing that the taxation shall be for the "general welfare," or, as it is frequently put, for a "public purpose." States and their subdivisions have been permitted to engage in a variety of enterprises under this limitation. ${ }^{34}$ The test is not rigid, but concerns itself with judgment as to need in each instance. It asks how great is the public need for the particular service; how. important to the life of the community is the service; how adequately or inadequately is it furnished by private enterprise; how extensively does the government propose to furnish it and how seriously does the government's activity interfere with private enterprise. What has already been said sufficiently answers these questions. For similar reasons the federal government is already in the banking business with its Land Banks and others and in the insurance business under the War Risk Insurance Act. The alleged enitry into and competition with private business is a ghost having no reality-but it is a ghost which may frighten, and fright may prompt unwise and unjustified action.

One further point. If we look into the expenditures for the purpose of discover-

${ }^{34}$ See, e.g., Green v. Frazier, 253 U. S. 233 (1920); Jones v. City of Portland, 245 U. S. 217 (1917). 
ing possible grounds for invalidating the taxes, we should not neglect the evidence thus made available for rebuttal of objections to the taxes. The scheme of benefits provided in Title II, if considered in connection with Title VIII, affords independent answer to the objections of inequality and due process previously discussed.

\section{TirLe IX}

Much of what has been said about Title VIII is, of course, equally applicable to the tax imposed by Title IX. Thus, the questions as to the selection of the employment of others as the subject of the tax, the exemption of certain employment and geographical uniformity need not be discussed again. The additional exemption of employers of less than eight employees should occasion no difficulty. Minor exercises of a privilege are commonly exempted from taxes on the privilege. The gift tax, the inheritance tax, the amusement tax all begin a little above the bottom, though the respective privileges are exercised when the gift or inheritance is below the taxable amount or the cost of the amusement cheaper. Likewise, the additional factor that credits upon the tax are allowed for payments under state laws and the state laws may vary, introduces no difficulty with respect to the requirement of uniformity. Geographical uniformity is still provided. The divergence is due not to the Act but to the uncontrolled distribution of the phenomena upon which the Act operates. Wherever the phenomenon occurs, the Act operates. Precisely similar divergence exists with reference to the credits and deductions for state tax payments allowed in the federal estate tax in the federal income tax. "Congress cannot accommodate its legislation to the conflicting or dissimilar laws of the several states nor control the diverse conditions to be found in the various states which necessarily work unlike results from the enforcement of the same tax. All that the Constitution (Article I, Section 8 , clause I) requires is that the law still shall be uniform in the sense that by the provisions the rule of liability shall be the same in all parts of the United States."35

The scheme of Title IX is modeled on the federal estate tax which passed muster before the Supreme Court in Florida v. Mellon." That tax may "be credited with the amount of any estate, inheritance, legacy, or succession taxes paid to any State," the credit not to exceed 80 per cent of the federal tax. The legislation was assailed on the ground that it constituted "an invasion of the sovereign rights of the state and a direct effort on the part of Congress to coerce the state into imposing an inheritance tax and to penalize it and its property and citizens for the failure to do so." Said the Court: "The act assailed [Section 30I of the Revenue Act of I926] was passed by Congress in pursuance of its power to lay and collect taxes, and, following the decision of this court in respect of the preceding act of I9I6, New York Trust Co. v. Eisner, 256 U. S. 345, must be held to be constitutional."37

Prior to the 1926 Act the credit upon the federal estate tax allowed for state tax

${ }^{85}$ Florida v. Mellon, 273 U. S. 12, 17 (1927).

"supra note 32.

${ }^{27}$ Id. at 16,17 . 
payments was not to exceed 25 per cent of the federal tax. ${ }^{38}$ At that time Florida, which had no inheritance tax, did not complain. It was still a favored and profitable state of domicile for persons of large estates. Then Section 301 of the I926 Act increased the credit to 80 per cent. It was that increase that made it insufficiently profitable for such persons to become domiciled in Florida. And it was that increased credit which Florida challenged as being less an attempt to raise revenue and more an attempt to coerce non-inheritance-tax states to impose inheritance taxes, or at least to remove Florida's advantage as a prospective state of domicile over the states which did have inheritance taxes. The characterization seemed quite apt. Here was an attempt to raise revenue which would obviously result in reducing revenue by some 75 per cent. Yet the tax is constitutional. It produces some revenue. It reduces, by the credit and not necessarily by the increase in the credit, the burden of cumulative taxation. It recognizes state policy and preserves sources for state revenue, though frustrating another state policy like that of Florida. It does not directly attempt to discourage or coerce action by individuals. And it does not attempt or hope to discourage the frequency of the subject taxed.

The legal form of Title IX is a faithful replica of its model. It, too, allows a credit only for money paid under compulsion of state law (except for the additional credit under Section gro, to be mentioned presently). It, too, will raise substantial revenue, even if all taxpayers become eligible for the credit. It hopes to encourage rather than discourage the frequency of the subject taxed. It, too, is designed to avoid cumulative taxation and permit the execution of state policy. The additional credit allowed by Section gro is but additional precaution against undue interference with state policy. If additional credit were not allowed, the Act would tend to proscribe a type of state unemployment compensation plan which is already in existence (viz., the "Wisconsin" or "employer reserve" plan) and for which there is a good deal of demand and promise. It would be quite paradoxical if such measures, enacted under an express power and designed to protect the states in the execution of their policies, were deemed to be invasions of the states' powers.

There are, however, some differences. Credit on the Title IX tax is allowed only for payment under such state laws as are found by the Social Security Board to comply with the conditions enumerated in Section 903. The conditions concern solely the provisions of the state laws under which the state payments are made by the taxpayers and relate only to the administration and expenditure of the funds collected; and the funds are required to be deposited in the Treasury of the United States. The conditions are in large part similar to those discussed earlier with reference to the grants-in-aid. Granted the power to tax and the power to allow credits for payments under state laws, it is difficult to find substantial constitutional ground for denying to Congress choice as to the kind of state laws that may qualify payments for the credit. This is not a purchase of compliance by individuals; the

${ }^{2 s}$ Revenue Act of I924, \$30I (b), 43 Stat. 304. 
choice is not theirs and they cannot comply. Nor is this less non-coercive upon the states than the common conditions in grants-in-aid or than the estate tax upon Florida.

The further difference that most states had inheritance taxes when the I926 Revenue Act was passed, while most states had no unemployment compensation laws when the Social Security Act was passed seems similarly insignificant. The point suggested is, of course, that because of this difference the latter act is in fact coercive though the former is not. But coercion in fact cannot be so blithely established. It is commonly believed that many states would have had unemployment compensation laws were it not for the fear of competition from states without such laws. If that is the fact, then the former states have been awaiting the opportunity made available by Title IX. On the other hand, at the time of the enactment of the Revenue Act of I926, or thereafter, there may have been states which desired to repeal or reduce their inheritance taxes but were deterred by that Act from doing so. Moreover, in almost all the states it became profitable to increase the inheritance taxes in order to take advantage of the increased credit. If the Ig26 change is regarded, rather than the initial smaller credit, the suggested difference disappears. There is no coercion in either case, as there is also no coercion in the grants-in-aid, because the same choice is provided. Congress may tax with an eye to the future as well as to the present.

If the argument thus far has carried conviction, there is no need for going farther. But there may still lurk a suspicion that we cannot "shut our eyes" to the fact that the purpose of the tax is to procure unemployment compensation and that somehow that makes a difference. The suspicion raises with respect to the Title IX tax the same issues which have already been discussed with respect to the Title VIII tax. Only little additional discussion is necessary.

Suppose that the tax were professedly levied for the establishment of a federal unemployment compensation fund to be collected, administered and expended by the federal government. Would it be within the power of Congress to lay taxes to provide for the common defense and general welfare? Are federal expenditures for unemployment relief, expenditures for a federal purpose, the general welfare? 'The question deserves the emphasis of Chief Justice White's favorite reply: merely to ask the question is to provide the answer. In a period of severe criticism of federal policy and federal spending almost no one is heard to say that the present unemployment is not a national problem, that the federal government should not or cannot spend its monies for the relief of unemployment. There are differencessharp or fancied-as to methods, projects, amounts and procedures. But all seem to agree that the federal government may and must feel a responsibility and attempt to discharge it. If, then, unemployment is a national ill, its cure would be obviously for the general welfare and Congress, therefore, may appropriate money for that purpose. Whether payment of money to the unemployed will in fact tend to relieve 
the ills of unemployment and thus promote the general welfare is a matter for legislative determination. But none will deny that the Congressional determination in the affirmative has abundant reasonable support.

If the payment of money to the unemployed is a proper federal expenditure, then the federal government may levy taxes in preparation for the outlay. The Act would provide for no more than the collection of taxes and the payment of benefits. Both powers are in terms granted to the federal government. No substantial issue under the Tenth Amendment would be involved. Neither the Constitution nor the spirit of federalism commands that relief for the unemployed or the aged is a matter for state concern. ${ }^{39}$ When the distress is or threatens to be national in scope and relief is necessary for the national welfare, the matter is one for federal concern. And the federal concern is here translated into action, not through some prohibited power of regulation, but solely through the granted power to tax and appropriate.

Nor would the due process clause present any serious obstacle. Concededly, the purpose of the tax would be to foster the general welfare. General welfare not simply because of the betterment of the lot of those unemployed for the time, but general welfare because of the stimulation or maintenance of industry and commerce through the greater stabilization of purchasing power. And general welfare by the prevention of demoralization and despondency and by the stimulation of confidence and loyalty in the populace, a federal concern, as pointed out above, in peace as well as war.

If the purpose of Title IX is to provide unemployment compensation on the basis of state administration under federal supervision, it is but an alternative method for a nationally administered unemployment compensation plan. With the latter available, the choice of the former can hardly be regarded as an invasion of powers reserved to the states. With power to supplant the states, Congress has instead invited them to precede. The wisdom of the choice has been discussed elsewhere. Its consistency with the spirit of federalism seems hardly open to question. At least, so it seems to me.

50 The use of the word "concern" is not meant as an acceptance of a particular theory as to the meaning of the Tenth Amendment. The Constitution, it has been pointed out, speaks of powers; and it is powers, not fields, subjects, or concerns, that are reserved to the states by the Tenth Amendment. See Collier, supra note 3, at 224. There may be much significance in the difference." But the present argument is addressed to the judicial rather than the constitutional term. Cf. the opinion of the Chief Justice in the T.V.A. case (56 Sup. Ct. at 479): "The constitutional provision is silent as to the method of disposing of property belonging to the United States. That method, of course, must be an appropriate means of disposition according to the nature of the property, it must be one adopted in the public interest as distinguished from private or personal ends, and we may assume that it must be consistent with the foundation principles of our dual system of government and must not be contrived to govern the concerns reserved to the States." The Social Security Act satisfies these requirements. 